Вісник Дніпропетровського університету. Серія: геологія, географія. 25 (1), 2017, 3 - 11.

Vìsnik Dnìpropetrovs'kogo unìversitetu. Seriâ Geologiâ, geographîâ

Dnipropetrovsk University Bulletin. Series: geology, geography. 25 (1), 2017, 3 - 11.

Doi: $10.15421 / 111701$

http://geology-dnu.dp.ua

УДК 565.2+551.782.12(477.63)

\title{
Остракоди крайових частин Борисфенської затоки Східного Паратетису в середньому сарматі
}

\section{О. В. Бондар, Г. Л. Самойленко}

Дніпропетровський національний університет імені Олеся Гончара, Дніпро, Украӥна, e-mail:olessiabondar@ukr.net

Наведено нові дані щодо палеоекології остракодів крайових частин Борисфенської затоки Східного Паратетису у середньому сарматі. Розглянуто два комплекси остракод із відслонень поблизу с. Новокиївка та смт Губиниха Дніпропетровської області, розташованих по периферії поширення середньосарматського моря. Проведено аналіз кількісного та систематичного складу ценозів, морфоскульптури черепашок, застосовано актуалістичний підхід до інтерпретації умов мешкання остракод. У комплексах знайдено три морські види, сім солонуватоводних видів морського генезису, один слабкосолонуватоводний вид неморського генезису, а також два евригалінні види. На основі аналізу екологічних груп остракодів зроблено висновки щодо солоності та температурного режиму, глибин та прозорості морського басейну, його гідродинамічних особливостей. Виявлено, що крайові частини середньосарматського моря характеризувалися невеликими глибинами - до 20 м, мулисто-піщаним субстратом, заростями водоростей, температурою близько $20^{\circ} \mathrm{C}$, нестабільним сольовим режимом, прозорість води була дещо погіршена через присутність фітопланктону та зважених мінеральних частинок.

Ключові слова: остракоди, міочен, середній сармат, палеоекологія, Борисфенська затока, Східний Паратетис

\section{Ostracoda of the marginal parts of the Borisphen Gulf of the Eastern Paratethys in the Middle Sarmatian}

\author{
O. V. Bondar, H. L. Samoilenko \\ Oles Honchar Dnipropetrovsk National University, Dnipro, Ukraine, e-mail: olessiabondar@ukr.net
}

This work continues the analysis of assemblages of ostracoda from the Middle Sarmatian deposits of the Borisphen Gulf of the Eastern Paratethys. Ivanova at al. (2007), Bondar (2015) present data on the history of the study of Sarmatian ostracods, on the factual data, methods of study, and lithological and palaeontological description of the composite Sarmatian sections of the marginal parts of the Borisphen Gulf. This publication presents a palaeoecological analysis of the ostracod assemblages, which contributes to the description of the shallow-marine environment which existed in the Middle Sarmatian basin. The material studied consists mainly of benthic ostracods, closely associated with the near-bottom environment of the basin. This makes them a reliable indicator of the palaeoecological environment. Any changes of the living environment is leaded to restructuring of the entire ostracod assemblage. The main environmental factors, influencing the systematic and quantitative composition, and the domination of one taxa over others, include water depth, salinity, hydrodynamic conditions in the basin, temperature conditions, substrate type, and organic carbonate and oxygen content of the water. The reconstruction of the palaeoenvironment is based primarily on the actualistic approach, where the environmental parameters of modem communities are extrapolated to the ancient fauna with certain assumptions. A total of 16 species of ostracod, belonging to 6 genera of 6 families, were identified in the Middle Sarmatian deposits. Investigation of these ostracod assemblages included taxonomic, quantitative, taphonomic and palaeoecological analyses. The palaeoecological analysis of ostracods from the deposits of the marginal parts Middle Sarmatian sea demonstrates that the assemblages developed in the more or less favorable environments of a warm shallow basin (deep up to $20 \mathrm{~m}$, temperature about $20^{\circ} \mathrm{C}$ ). Limited diversity of the species, abundance of certain specimens, large and heavy shells of ostracods are typical of the shallowest parts of a basin with active hydrodynamic environments (Aurila). The highest taxonomic diversity of the ostracod associations was encountered in the fairly shallow and calm environments with low sorting of substrate and weak near-bottom hydrodynamics (Loxoconcha, Leptocythere). The salinity of the basin was unstable. So there are Cyprideis torosa, Cyprinotus luminosus in the assemblages. Keywords: ostracoda, Miocene, Middle Sarmatian, palaeoecology, Borisphen Gulf, Eastern Paratethys

Вступ. Остракоди - це великий підклас мікроскопічних ракоподібних, тіло яких поміщене в двостулкову вапнисту черепашку.
Вони чудово зберігаються у викопному стані та відомі починаючи з кембрію, нині населяють усі можливі водні біотопи, від океанічної 
ультраабісалі до підземних вод та вологих наземних місць проживання, утворюючи у кожному з них специфічні комплекси видів.

Остракоди належать до однієї 3 найбільш поширених груп мікрофауни в міоценових, зокрема сарматських, відкладах різного генезису. Через свою широку екологічну валентність ці організми вельми перспективні за своєю інформативністю для цілей стратиграфії, палеоекології та палеогеографії відкладів, в яких вони зустрінуті, зокрема сарматських відкладів Східного Паратетису. Аналіз екологічних груп остракод дозволяє зробити висновки щодо солоності й температурного режиму, коливань глибин морського басейну, його зв'язків із палеобасейнами суміжних територій i таким чином деталізувати історію Східного Паратетису у сарматський час. Особливості у розвитку комплексів, які проявляються у зміні таксономічного та кількісного складу, є відображенням трансгресивно-регресивних циклів у палеобасейні району досліджень.

До основних зовнішніх факторів, які впливають на остракоди та визначають особливості таксономічного складу комплексів, належать: солоність, температура, глибина, прозорість та рухомість води, субстрат, вміст кисню у водній масі. Спосіб існування остракодів тісно пов'язаний із придонними умовами басейну, що робить їх надійними індикаторами палеоекології. Важливий фактор контролю у поширенні спільнот остракодів - це температура. Виділяють евритермні види, які зазвичай найбільше розповсюджені, стенотермно-холодолюбні (арктичні види та представники весняної фауни остракодів) та стенотермні-теплолюбні (літні форми остракод). Стосовно глибини остракод відносять до еврибатної групи, але переважно вони мешкають на мілководді, багатому на водорості. Гідродинамічні умови басейну мешкання відновлюють не тільки за характером захоронення залишків, а й за формами черепашок. Великий відсоток черепашок ювенільних стадій та низький відсоток уламкового черепашкового матеріалу свідчать про відносно спокійні умови осадконакопичення. Форма та скульптура черепашок характеризують характер субстрату басейну мешкання остракод (Nikolaeva at al., 1989).

Мета роботи - реконструкція палеоекологічних умов крайових частин Борисфенської затоки Східного Паратетису у середньому сарматі за даними вивчення остракод.
Матеріали та методи досліджень. Матеріалом для досліджень стали черепашки остракодів із відкладів середнього сармату, розкритих піщаним кар'єром, розташованим неподалік від смт Губиниха Дніпропетровської області, та відслонення на березі Каховського водосховища поблизу с. Новокиївка Дніпропетровської області. (рис. 1 - 4). Дещо раніше породи цих розрізів отримали комплексну палеонтологічну та літологічну характеристику (Bondar, 2015; Ivanova at al., 2007).

Остракод проаналізовано згідно зі стандартними методиками палеонтологічних досліджень (Nikolaeva at al., 1989): технічна обробка зразків, мікроскопічне вивчення, фотографування, зарисовки, застосування математичних методів та методів палеоекологічного аналізу (морфофункціональний, актуалістичний, тафономічний та кількісний).

Розрізи досліджених відслонень наведено на рисунку 2.

У зразках знайдено 16 видів остракод iз 6 родів, які належать до одного підкласу, одного ряду, 6 родин та 3 підродин.

Результати досліджень. Унаслідок комплексних палеонтологічних досліджень відслонення міоценових відкладів району смт Губиниха Дніпропетровської обл. (південно-східна частина Дніпровсько-Донецької западини) (рис. 1, 2) утворення середнього сармату (бессарабський регіопід'ярус) були стратифіковані на новомосковські, василівські та дніпропетровські верстви (Ivanova at al., 2007). Остракоди зустрінуті тільки у нижній частині розрізу, тобто у новомосковських верствах, представлених пухкими піщано-детритовими монтморилонітгідрослюдистими породами світло-сірого кольору, що у крівлі переходять у глини піщанодетритові $з$ жовтувато-зеленуватим відтінком. У середині товщі спостерігається прошарок білого міцного перекристалізованого вапняку 3 відбитками черепашок пелеципод, ядрами форамініфер та остракод роду Cyprideis поганої збереженості. У піщано-глинистих відкладах виділено комплекс остракод: Loxoconcha insigna Iln., L. alveolata Vor., L. decorata Bond., Leptocythere mironovi (S c h n.), L. scabrida S u z., Xestoleberis cf. elongata Schn., Aurila notata (Reuss), A. mehesi (Zal.), A. aff. angularis (Schn.), A. sp., Cyprideis torosa (Jones), Cyprinotus luminosus Iln., який доповнюється детритом та цілими черепашками двостулкових молюсків, форамініферами, отолітами риб. 
Видима потужність утворень 0,30 - 0,45 м. Перекриваються вапняками василівських верств середнього сармату.

Подібна остракодова асоціація, однак, дещо таксономічно збіднена, виявлена у відкладах, розкритих відслоненням на північному узбережжі Каховського водосховища поблизу с. Новокиївка (рис. 1, 2, 4) (Bondar, 2007). Тут нижче верхньосарматських глин iз поодинокими Cyprideis torosa (J o n e s) визначено породи середнього сармату, які складені глинами світло-сірими 3 лінзами піску, детритом молюсків, форамініферами та численними остракодами: Leptocythere mironovi (S chn.), L. aff. plana (S c h n.), L. sp. indet., Xestoleberis lutrae S chn., Loxoconcha laevatula Liv., L. decorata
Bond., Aurila aff. laevis (S c h n.), Cyprideis torosa (Jones), C. punctillata (Brady).

Шельфова зона морських басейнів $\epsilon$ місцем існування багатьох організмів, у тому числі остракод. Останні, особливо у прибережній зоні 3 іi мінливими екологічними умовами, складають значну кількість специфічних спільнот, пов'язаних із певними глибинами, субстратом, гідродинамікою, солоністю та які мають характерну таксономічну структуру i вміст домінуючих форм. Остракоди - одна 3 найпоширеніших груп фауни сарматського моря. Чутливість до змін умов навколишнього середовища визначає можливість їх використання для біономічних реконструкцій палеобасейну.

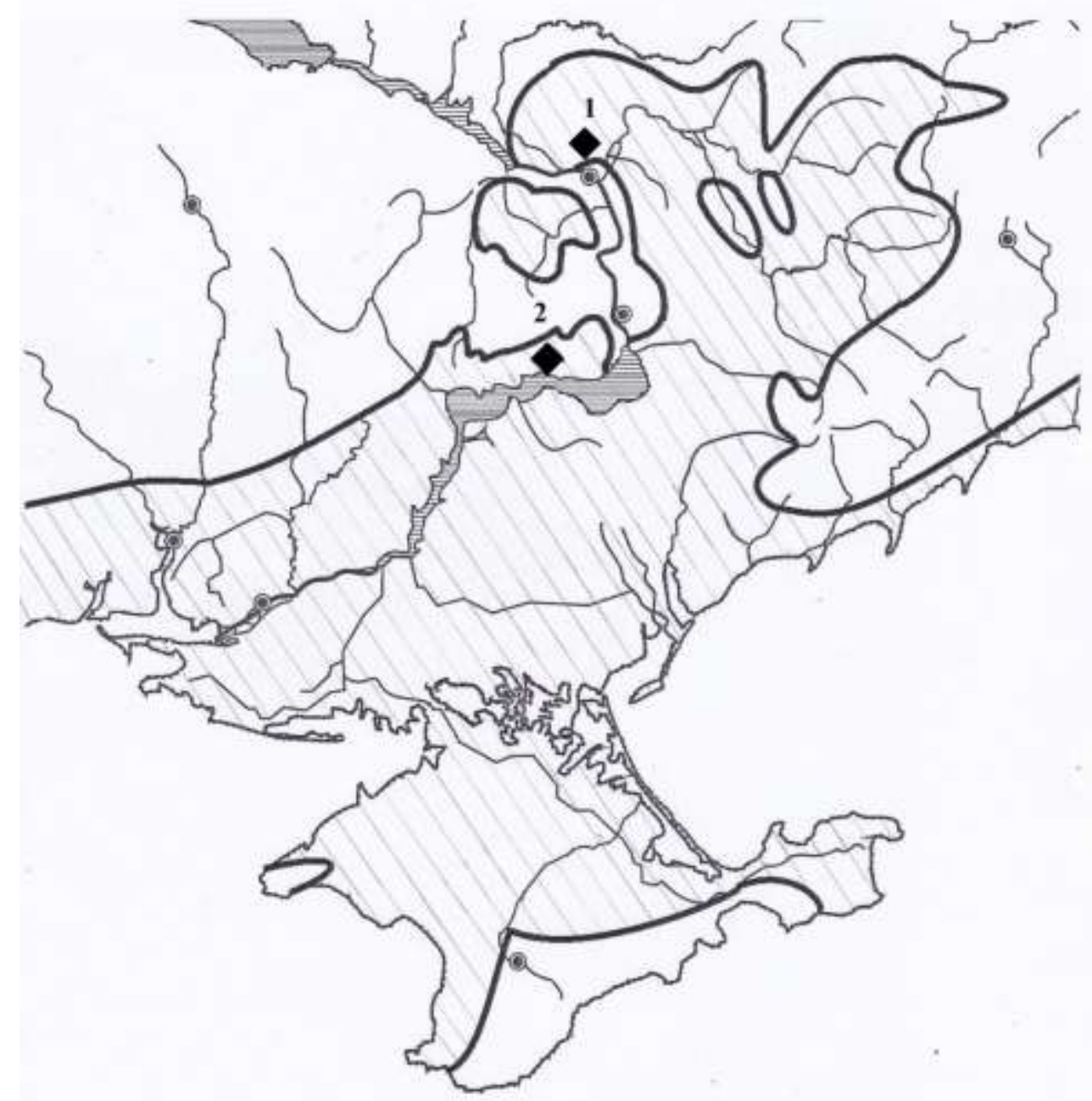

Рис. 1. Схема розташування відслонень: 1 - смт Губиниха; 2 - с. Новокиївка, 110 - територія поширення середньосарматського моря у новомосковський час (Belokrys, 1976) 
Формування сарматського моря, одного 3 найбільших у міоценовій історії Паратетису, в межах території досліджень визначалося тектогенезом Гірського Криму (Chekunov, 1976) та змінами клімату (Belokrys, 1984; Korallova, 1989). Протягом сармату цю територію вкривали моря, основні біономічні показники яких неодноразово змінювались у часі.

Досліджуваний комплекс остракодів охарактеризований 3 морськими видами, 7 солонуватоводними видами морського генезису, одним слабкосолонуватоводним видом неморського генезису, а також 2 евригалінними видами.

У подокопід прибережної зони моря спостерігається декілька способів пристосування до умов рухливих вод. Деякі остракоди мають легкі обтічні черепашки, в інших - черепашки сильно дорсовентрально сплощені або масивні 3 дещо згладженою скульптурою, принаймні у верхній частині (Schornikov, 1971).

Значну частину ценозів складають види родів Leptocythere, Aurila, Loxoconcha, Xestoleberis. Представники роду Leptocythere, ряд видів роду Aurila, а також Xestoleberis, досить вільно можуть пересуватися по різноманітних субстратах. Біля відкритих берегів їх можна спостерігати у хащах дрібних водоростей, під камінням та в інших притулках, захищених від прямої дії хвиль. У більш спокійних місцях вони розповзаються на водорості, пісок, можуть зустрітися навіть на мулі, але неподалік від твердого субстрату.

Деякі представники родини Loxoconchidae успішно заселяють великі водорості. Види 3 витончено скульптурованою черепашкою, як, наприклад, Loxoconcha decorata Bond., характерні для заростей морської трави та мулистого субстрату, що підкреслюється поздовжньою ребристістю, полегшеністю черепашки та наявністю крилоподібних виступів. Вони обирають спокійні місця мешкання, зазвичай глибше 1,5 м. Шипуватість черепашки лише опосередковано пов'язана зі субстратом мешкання i, вірогідно, виконує захисні функції. Формування масивних черепашок обмежене необхідністю мати легкі конструкції у випадку мешкання на поверхні хиткого субстрату. Крім того, зі зростанням глибини мешкання набуває значення економія матеріалу через ускладнення засвоєння солей кальцію.

У задньочеревній частині Loxoconcha decorata $є$ крилоподібний виріст, який може виконувати зразу декілька функцій та слугувати:
1) додатковою площею опору, що перешкоджає провалюванню організму в осад; 2) несною площиною під час пересування по поверхні пухкого осаду; 3) як супорт, що підвищує стійкість черепашки на твердому субстраті; 4) як присоска (Schornikov, Zenina, 2014). Залежно від конфігурації виросту може превалювати одна 3 функцій. Через різноманітність його призначень серед різних груп остракод утворено багато конвергентних форм, часто сильно спеціалізованих завдяки удосконаленню однієї 3 функцій.

У Loxoconcha decorata крилоподібний виріст має трикутний обрис, він дещо похилений через опускання його задньої частини, завдяки чому під час руху організму пухким субстратом створюється підйомна сила, яка виштовхує його уверх на поверхню грунтів. Така форма характерна для остракод - мешканців мулистих грунтів. Представники роду Loxoconcha 3 чітко вираженою скульптурою черепашки обирають спокійні місця. Біля відкритих берегів вони зустрічаються звичайно глибше 1,5 м спільно 3 остракодами 3 масивною, розширеною у нижній частині черепашкою 3 пласкою нижньою поверхнею, які навіть можуть проникати до зони прибережних скелью. Навали каміння, гравію та детриту - сприятливі місця мешкання для багатьох остракод, характерних як для твердих, так і пухких грунтів. У остракод, спеціалізованих для мешкання на щільному субстраті - чистому піску, детриті, гальці, каменях - крилоподібний виступ утворює одну площину 3 нижньою частиною, завдяки чому зростає стійкість черепашки. Це дає змогу успішно протистояти перевертанню в умовах сильної рухливості води. Нижня поверхня черепашки має добре розвинені не тільки поздовжні, а й поперечні ребра, що підвищує тертя та перешкоджає знесенню. Поперечні ребра не заважають руху, тому що організм не волочить, а піднімає черепашку, спираючись на жорсткі грунти.

У прибійній зоні відкритих берегів завглибшки 5 м на твердих грунтах масово мешкають остракоди роду Xestoleberis. Його представники 3 відносно роздутими овальними або брунькоподібними черепашками, як, наприклад, у Xestoleberis lutrae Schn., X. elongata Schn., характеризуються деякою політопністю.

Види 3 полегшеною гладенькою подовженою черепашкою, до групи яких належать Leptocythere mironovi (S c h n.), L. aff. 


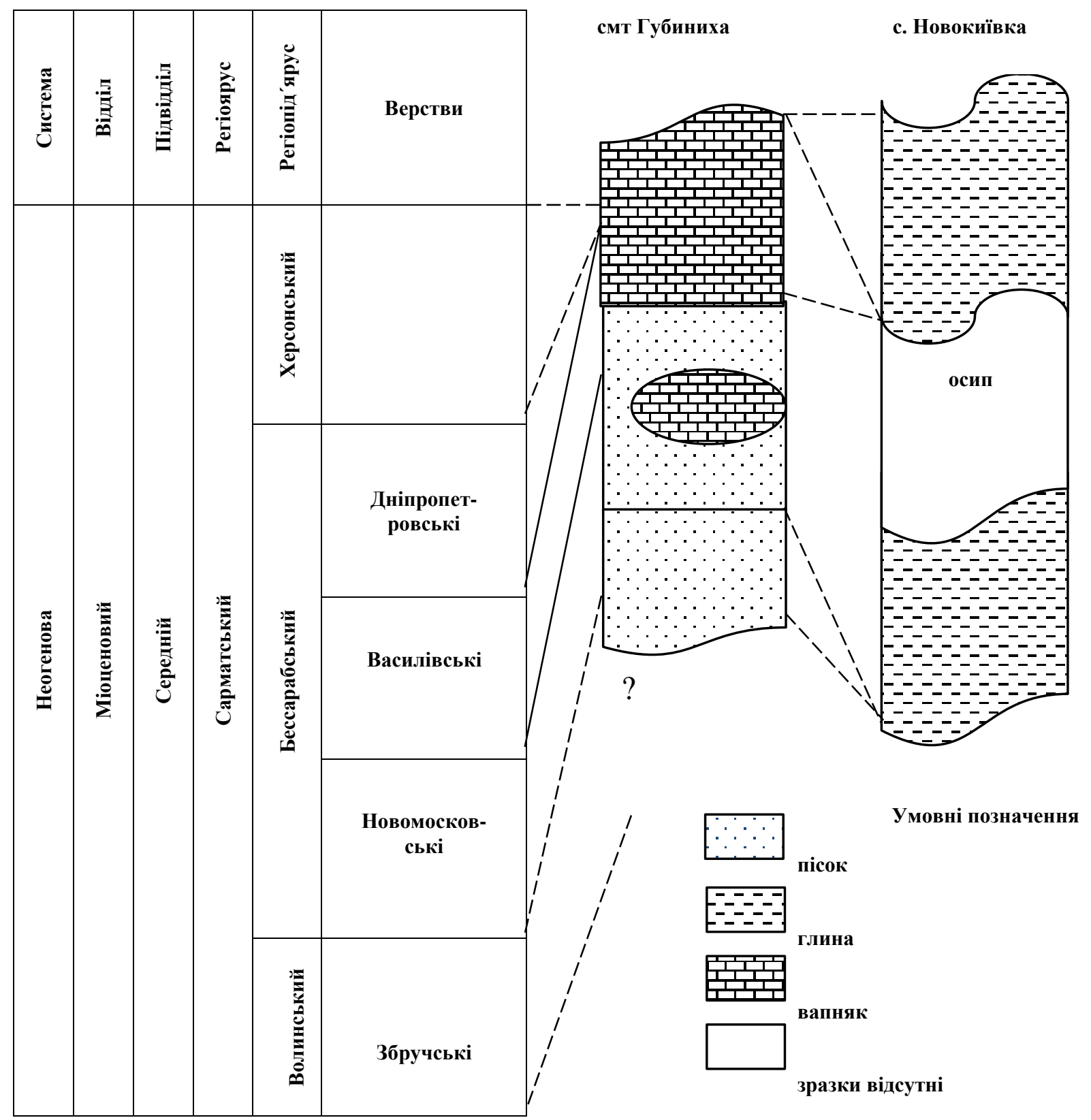

Рис. 2. Схема кореляції досліджуваних розрізів 

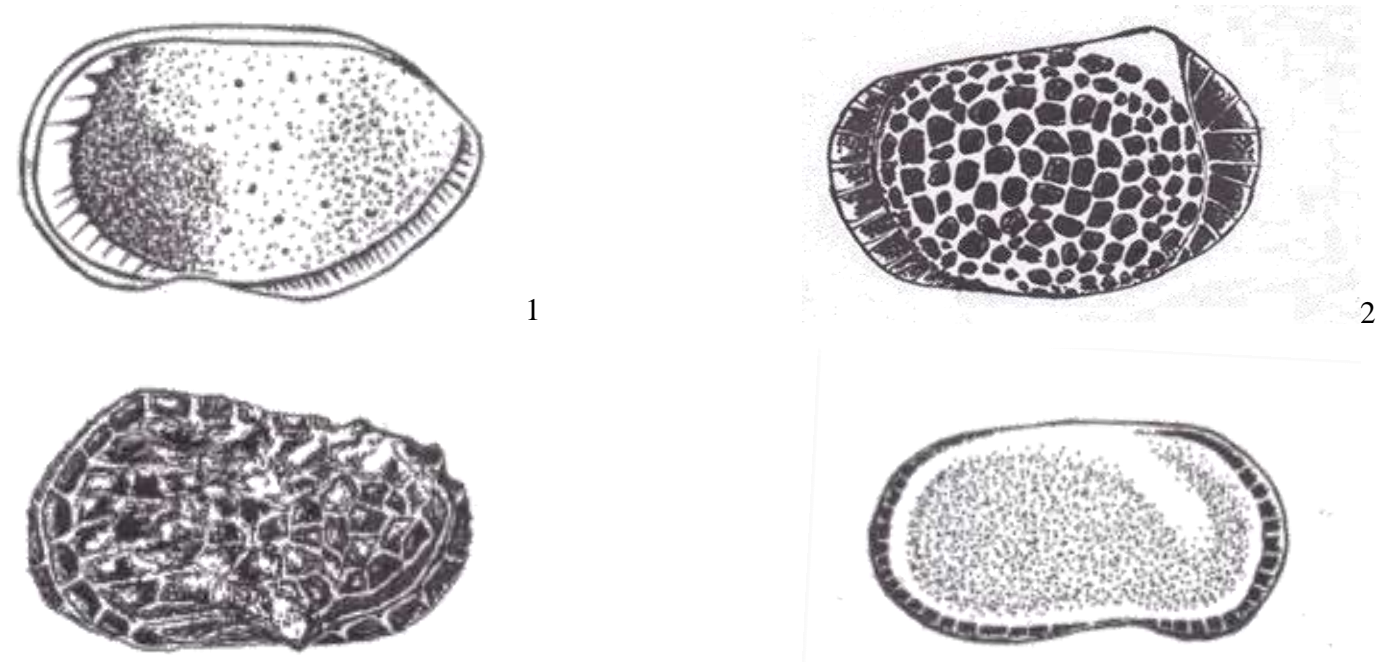

3

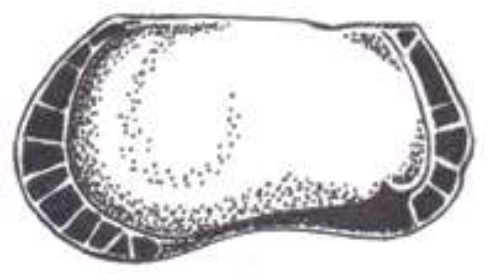

5
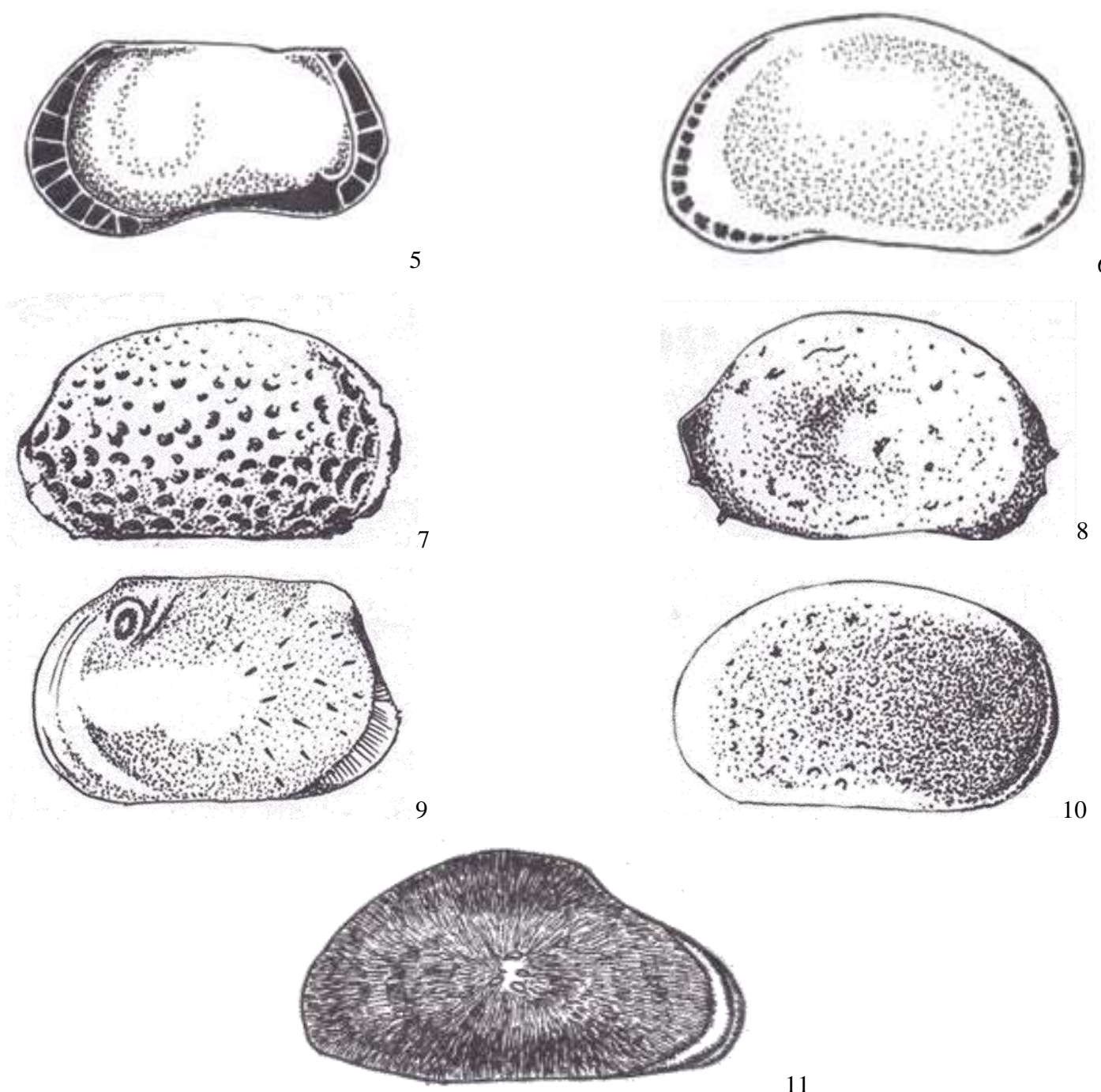

11

Рис. 3. Комплекс остракод з відслонення поблизу смт Губиниха: 1 - Loxoconcha insigna Iln. (ліва стулка із зовнішнього боку, х 60), 2 - Loxoconcha alveolata Vor. (права стулка із зовнішнього боку, х 80), 3 - Loxoconcha decorata B ond. (ліва стулка із зовнішнього боку, х 90), 4 - Leptocythere mironovi (Schn.) (права стулка із зовнішнього боку, х 60), 5 - Leptocythere scabrida Suz. (ліва стулка із зовнішнього боку, х 80), 6 - Xestoleberis elongata Schn. (ліва стулка із зовнішнього боку, х 70), 7 - Aurila notata (Reuss) (права стулка із зовнішнього боку, х 50), 8 - Aurila mehesi (Zal.) (права стулка із зовнішнього боку, x 50), 9 - Aurila aff. angularis (Schn.) (ліва стулка із зовнішнього боку, х 50), 10 - Cyprideis torosa (Jones) (ліва стулка із зовнішнього боку, х 50), 11 - Cyprinotus luminosus Iln. (права стулка із зовнішнього боку, $x$ 50) 

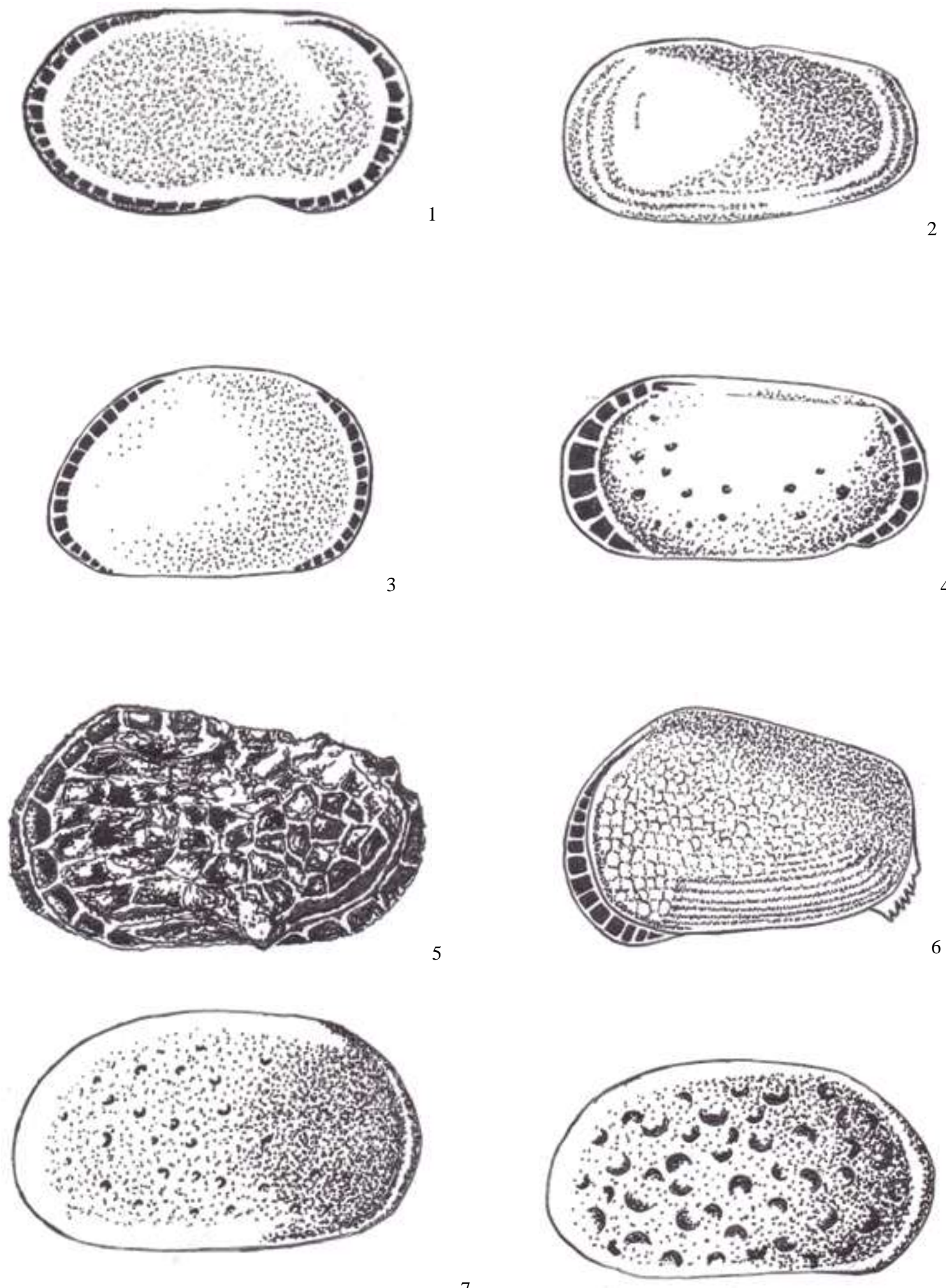

7

Рис. 4. Комплекс остракод із відслонення поблизу с. Новокиївка: 1 - Leptocythere mironovi (Schn.) (права стулка із зовнішнього боку, х 85), 2 - Leptocythere aff. plana (Schn.) (ліва стулка із зовнішнього боку, х 100), 3 Xestoleberis lutrae Schn. (ліва стулка із зовнішнього боку, х 110), 4 - Loxoconcha laevatula Liv. (права стулка із зовнішнього боку, х 90), 5 - Loxoconcha decorata Bond. (ліва стулка із зовнішнього боку, х 130), 6 - Aurila aff. laevis (Schn.) (ліва стулка із зовнішнього боку, х 80), 7 - Cyprideis torosa (Jones) (права стулка із зовнішнього боку, х 70), 8 - Cyprideis punctillata (Brady) (права стулка із зовнішнього боку, х 60) 
plana (Schn.), зустрічаються на мулах та риються у грунтах. Черепашки 3 комірковою скульптурою, представлені Leptocythere scabrida S u z., також можуть ритися у грунтах і досягати на мулах значної чисельності. Багато їх i на замуленому піску та детриті. Для остракод намул на твердому субстраті, товщиною всього у 2 3 мм, вже буде справжнім мулом. На такий субстрат можуть також проникати i спеціалізовані мулисті форми. В зонах моря 3 активною гідродинамікою можливе перенесення стулок остракод із місця на місце (Schornikov, Zenina, 2014).

Округлі, вкорочені, грубо скульптуровані товстостінні черепашки видів роду Aurila вказують на піщаний субстрат морської літоралі та активну гідродинаміку даної ділянки басейну.

Присутність у складі комплексу представників сучасних форм дозволяє екстраполювати умови ї теперішнього існування на палеобасейни. Так, Cyprideis torosa (Jones) - евригалінний вид великого стратиграфічного поширення, який зустрічається переважно в басейнах із нестійким сольовим режимом, а також в умовах майже повного обміління та опріснення. Переносить коливання солоності від прісної води до 38 \%, наймасовіші популяції утворює на ділянках із непостійним сольовим режимом із солоністю $2-8 \%$. Найчастіше він присутній на мулах, серед рослинності на глибині від 0,5 до $20 \mathrm{M}$, комфортна температура води - до 10 - 16 ${ }^{\circ} \mathrm{C}$ (Dykan, 2006). На незначне опріснення вказує також присутність у комплексі Cyprinotus luminosus Iln., що $\epsilon$ мешканцем солонуватоводних та прісноводних басейнів. Узагалі, представники родини Cyprididae займають різноманітні екологічні ніші, але віддають перевагу водоймам із багатою рослинністю (Nikolaeva at al., 1989).

Для встановлення палеоглибин використовується також здатність деяких бентосних остракод формувати горбики ока прозорі лінзоподібні стовщення, які концентрують світло та розташовані на поверхні черепашки над органами зору. Їх розмір та опуклість зростають зі збільшенням глибини мешкання та зменшенням освітлення (Kontrovitz, Myers, 1988; Myers, Kontrovitz, 1987; Zaharov, 2016). Найбільші горбики характеризують мешканців зовнішнього шельфу (починаючи 3 глибин $50-60 \mathrm{м})$, у видів, що мешкають на континентальному схилі, розмір горбиків поступово зменшується i вони повністю зникають нижче позначки 600 м. Формула розрахунку абсолютних палеоглибин установлює залежність розміру горбика ока у сучасних остракод від глибини (Kontrovitz, Myers, 1988; Myers, Kontrovitz, 1987). Проте на невеликих глибинах на розвиненість горбика ока у деяких видів родів Aurila та Loxoconcha імовірно впливає також забрудненість води мінеральними частинками та фітопланктоном.

Висновки. Остракоди - одна 3 найкращих груп організмів-індикаторів придонних екологічних обстановок. Вони різноманітні не тільки в морських та солонуватоводних, а й у прісноводних водоймах, швидко реагують на зміни глибин, солоності, гідродинаміки та інших параметрів басейнів проживання i вельми перспективні для використання як індикаторів у екологічних дослідженнях. Застосування методів палеоекологічного аналізу дозволило виділити палеоценози остракод, характерних для певних умов мешкання в межах мілководних ділянок крайових частин середньосарматського моря.

Таким чином, крайові частини середньосарматського моря у новомосковський час характеризувалися невеликими глибинами до 20 м, мулисто-піщаним субстратом, заростями водоростей, температурою близько $20{ }^{\circ} \mathrm{C}$, що контролювалася помірно вологим та теплим кліматом початку середнього сармату (Belokrys, 1984; Korallova, 1989). В них існували остракоди 3 різними вподобаннями мешкання: від ділянок 3 активною гідродинамікою до захищених від прямої дії хвиль затишних притулків (у комплексах поєднані представники різних екологічних груп). Сольовий режим був нестабільним, незначне опріснення водойми підкреслюється присутністю переважної кількості солонуватоводних та евригалінних видів остракод. Прозорість води акваторії була дещо погіршена через наявність фітопланктону та зважених мінеральних частинок.

\section{Бібліографічні посилання}

Belokrys, L.S., 1976. Sarmat yuga USSR [Sarmatian of the south of USSR]. Stratigrafiya kajnozoya Severnogo Prichernomor'ya i Kryma, 3-21 (in Russian).

Belokrys, L.S., 1984. Klimaticheskie izmeneniya v miocenovuyu ehpohu v ChernomorskoKaspijskoj oblasti i ih vliyanie na gidrologiyu bassejna i sedimentacionnye processy [Climatic changes in the Miocene epoch in the Black SeaCaspian region and their influence on the 
hydrology of the basin and sedimentation processes]. Stratigrafiya kajnozoya Severnogo Prichernomor'ya i Kryma, 10-21 (in Russian).

Bondar, O.V., 2007. Biostratyhrafiia seredno- ta verkhnomiotsenovykh vidkladiv Pivdennoi Ukrainy za ostrakodamy [Biostratigraphy of the Southern Ukraine Middle and Upper Miocene deposits by ostracods]. Dniepropetrovsk (in Ukrainian).

Bondar, O.V., 2015. Novyi vyd ostrakodiv rodu Loxoconcha z sarmatskykh vidkladiv Cerednoho Prydniprov'ia [A new ostracods' species of genus Loxoconcha from Sarmatian deposits of the Middle Dnieper region]. Paleontolohichnyi zbirnyk, № 47, 96-100 (in Ukrainian).

Chekunov A.V., Veselov A.A., Gil'kman A.I., 1976. Geologicheskoe stroenie i istoriya razvitiya Prichernomorskogo progiba [The geological structure and history of development of the Black Sea depression]. Naukova dumka, Kyiv (in Russian).

Dykan, N.I., 2006. Systematyka chetvertynnykh ostrakod Ukrainy: dovidnyk-vyznachnyk [Systematization of quaternary ostracoda of Ukraine (a reference book)]. IGN NANU, Kyiv (in Ukrainian).

Ivanova, T.A., Barg, I.M., Bogdanovich, E.M., Bondar, O.V., Stefansky, V.L., Petrenko, A.A., Stefansky, M.V., Majboga, I.E., 2007. Opornyj razrez miocenovyh otlozhenij yugo-vostochnoj chasti Dneprovsko-Doneckoj vpadiny (p.g.t. Gubiniha) [Demonstrative section of Miocene deposits of the south-eastern Dnieper-Donetz depression (country Gubiniha)]. Paleontolohichni doslidzhennia v Ukraini: istoriia, suchasnyi stan ta perspektyvy, Kyiv, 306-314 (in Russian).
Kontrovitz, M., Myers J.H., 1988. Ostracode eyes as paleoenvironmental indicators: physical limits of vision of some podocopids. Geology, V.16, 293-295.

Korallova, V.V., 1989. Klimat sarmatskogo veka na Ukraine (po palinologicheskim dannym) [The climate of the Sarmatian century in Ukraine (according to palynological data)]. Geologicheskij zhurnal, № 1, 69-74 (in Russian).

Myers J.H., Kontrovitz M., 1987. Geometrical optics of some ostracod eyes. Evolutionary biology of Ostracoda, Tokyo, Kodansha, 187193.

Nikolaeva, I.A., Pavlovskaja, V.I., Karmishina, G.I, Kovalenko, A.L., Aladin N.V, 1989. Prakticheskoe rukovodstvo po microfaune, 3. Ostrakody kainozoja [Practical manual on microfauna of the USSR, 3. Cenozoic ostracoda]. Nedra, Leningrad (in Russian).

Schornikov, E.I.,1971. Funkcional'naya morfologiya rakovin ostrakod kak paleoehkologicheskij indikator [Functional morphology of the shells of ostracods as a paleoecological indicator]. Tez. III Vsesoyuz. kollokviuma po ostrakodam. Tallinn, 36-39 (in Russian).

Schornikov, E.I., Zenina, M.A., 2014. Ostrakody kak indikatory sostoyaniya i dinamiki vodnyh ehkosistem (na primere zaliva Petra Velikogo Yaponskogo morya) [Ostracods as indicators of conditions and dynamics of water ecosystems]. Dalnauka, Vladivostok (in Russian).

Zaharov, V.A., 2016. Glubiny paleobassejnov i podhody $\mathrm{k}$ ih rekonstrukcii [Depths of paleobasins and approaches to reconstruction]. Paleontologiya, stratigrafiya, astrobiologiya, Moscow, 208-228 (in Russian). 